\title{
Essential Features of Process Fluids Applied in Machining
}

Jan Jersák, Jan Žižka

Department of Machining and Assembly, Faculty of Engineering, Technical University of Liberec, Studentská 2, 46117 Liberec, Czech Republic.Email: jan.jersak@tul.cz, janzpernstejna@gmail.com

Not only engineering production at present is characterized by increasing an international competition. It is achieved higher productivity with simultaneous improvement of quality parameters of machined parts by using of process fluids. In other words, the use of process fluids positively improves and increases the both the qualitative as well as quantitative parameters of the technological processes. Process liquids in machining occupy an important place and influence the outcome of the all processes. Choosing a suitable process fluid should be carefully considered. It is well known that, different machining technologies have different cutting conditions and thus completely different requirements on process fluids. Selection of a suitable process fluid is more important that the management of manufacturing companies admits. Unfortunately, the selection of suitable process fluids is very often underestimated.

Keywords: machining process, process fluids, lubrication, cooling

\section{Acknowledgement}

This article has been funded with support from the state budget through the Czech Republic - Technology Agency of the Czech Republic (Project TA02021332).

\section{References}

[1] A Windows into tribology - TTT Tapping Tourque Test System. [online]. Microtap GmbH, 2015. [cit. 01. srpna 2015]. Dostupné na: https://www.tapping-torque-test.com/en/.

[2] BAKALOVA, T., LOUDA, P., VOLESKÝ, L., BORU゚VKOVÁ, K., SVOBODOVÁ, L. (2015). Nanoadditives $\mathrm{SiO}_{2}$ and $\mathrm{TiO}_{2}$ in Process Fluids. Manufacturing Technology. Vol. 15, September, No. 4. s. 502 - 508. ISSN 12132489.

[3] BARTUŠEK, T., JERSÁK, J. (2009). Metoda MQL a její vliv na technologické parametry procesu broušení. Strojirrenská technologie. Rec. prof. Mádl. 14. roč., březen, č. 1. s. 12 - 18. ISSN 1211-4162 .

[4] BARTUŠEK, T. (2008). Účinek procesní kapaliny na technologii broušení a kvalitu obrobených součástí. [Diplomová práce]. Liberec, TU v Liberci. $67 \mathrm{~s}$.

[5] BENEŠ, P. (2009). Chladicí a mazací schopnost procesních kapalin při obrábění. [Diplomová práce]. Liberec, TU v Liberci, $78 \mathrm{~s}$.

[6] BUMBÁLEK, B., OŠŤÁDAL, B., ŠAFR, E. (1963). Řezné kapaliny. 1. vyd. Praha: SNTL. 136 s. ISBN -.

[7] DIN 51360-2. Testing of cooling lubricants; determination of corrosion preventing characteristics of cooling lubricants mixed with water; chip/filter paper method. Jul 1981. Berlin: DIN Deutsches Institut für Normung e. V.

[8] DUGIN, A., JERSÁK, J., POPOV, A. (2014). Method for Determining of the Anti-adhesion Ability of Cutting Fluids. Manufacturing Technology. Vol. 14, June, No. 2. s. 145 - 149. ISSN 1213-2489.

[9] DUGIN, A., VOLESKY, L. (2014). Effect of Cutting Fluids on the Tool Life in Turning and Milling of Construction Steel. Manufacturing Technology. Vol. 14, No. 3. s. 290-296. ISSN: 1213-2489.

[10]DUGIN, A., VOTOCEK, J., POPOV, A. (2014). Method for Determining the Tribological Properties of the Cutting Fluid. Manufacturing Technology. Vol. 14, No. 2. s. 149-153. ISSN: 1213-2489.

[11]GABRIEL, V., HOLUB, L., JERSÁK, J. (2000). Ověření vlastností řezných olejư při podélném soustružení: Výzkumná zpráva. Liberec: TU v Liberci, prosinec. $181 \mathrm{~s}$.

[12]JERSÁK, J., POPOV, aj. Ekologické obráběcí kapaliny nové generace. Rec. F. Holešovský. 1. vyd. Liberec: Technická univerzita v Liberci, 2014. 88 s. ISBN 978-80-7494-142-9.

[13]JERSÁK, J., PAVLÍK, J. (2013). Rešerše - výzkumný projekt TA2-1332 Ekologické obráběcí kapaliny nové generace. Výzkumná zpráva. Liberec: TU v Liberci, březen. $25 \mathrm{~s}$. 
[14]JERSÁK, J., POHOŘALÝ, M., ŽIŽKA, J. (2004). Monitoring of Grinding Process. Manufacturing Technology. Vol. 4, October, No. -, s. 45 - 48. ISSN 1213-2489.

[15]JERSÁK, J., VRKOSLAVOVÁ, L. (2013). The Influence of Process Fluids on the Properties of the Surface Layer of Machined Components. Manufacturing Technology. Vol. 13, December, No. 4. s. 466 - 473. ISSN 1213-2489.

[16] KAPLAN, F. (2012). Metodiky zkoušek obráběcích kapalin a jejich hodnocení při čelním frézování. [Bakalářská práce]. Liberec, TU v Liberci, $57 \mathrm{~s}$.

[17]KOCMAN, K., PROKOP, J. (2000). Technologie obrábění. 1. vyd. Brno: Akademické nakladatelství CERM, s.r.o., ISBN 80-214-1996-2.

[18] KREJČÍ, O. (2013). Zjištování vlivu procesních kapalin na jakost obrobeného povrchu a trvanlivost nástroje při vrtání konstrukční oceli. [Bakalářská práce]. Liberec, TU v Liberci, $62 \mathrm{s.}$

[19] MÁDL, J., KOUTNÝ, V. (2002). How to Select Suitable Cutting Fluid. Manufacturing Technology. Vol. 2, June, č. -. s. 45 - 53. ISSN 1213-2489.

[20]MÁDL, J. (2002). Dry Machining Versus Cutting With Cutting Fluids. Manufacturing Technology. Vol. 2, June, č. -. s. 42 - 45. ISSN 1213-2489.

[21]Měrení ochlazovací rychlosti kalicích médií - Quench test. TU Liberec [cit. 01. srpna 2015]. Dostupné na: http://www.kmt.tul.cz/edu/podklady_kmt_bakalari/TZZ/cv\%20quench.PDF

[22] NOVÁK, P. (2005). Návrh metodiky hodnocení procesních kapalin při osových operacích obrábění. [Disertační práce]. Praha, ČVUT Praha, $142 \mathrm{~s}$.

[23]POHOŘALÝ, M., JERSÁK, J. (2003). Výzkum vybraných parametrů jakosti broušeného povrchu v závislosti na povaze použitého chladicího média. Strojírenská technologie. Rec. F. Holešovský. Prosinec, 8, č. 4. s. 4 - 8. ISSN 1211-4162.

[24]Prodloužení životnosti řezných kapalin. MM Průmyslové spektrum [cit. 01. srpna 2015]. Dostupné na: http://www.mmspektrum.com/clanek/prodlouzeni-zivotnosti-reznych-kapalin.html

[25]STŘELCOVÁ, R. (2008). Řezné kapaliny a jejich uplatnění v moderní výrobě. [Bakalářská práce]. Brno: Vysoké učení technické v Brně, 48s.

[26]ŠAFR, E., DYK, A. (1956). Technika mazání v průmyslových závodech. 1. vyd. Praha: SNTL, 425 s. ISBN-.

[27]ŠTĚPINA, V., VESELÝ, V. (1985). Maziva v tribologii. 1. vyd. Bratislava: Veda, 406 s. ISBN-.

[28]ČILLÍKOVÁ, M. (2008). Top trendy v obrábaní - VI. čast' - Procesné médiá., aj. Žilina: MEDIA/ST, s.r.o., Január, ISBN 978-80-969789-3-9.

[29]ZIELASKO, W., ZIMMERMANN, M., HANKE, M. (2005). Hochleistungszerspanung, Trockenbearbeitung und Minimalmengenschmierung im Automobilbau (Fachtagung „Innovative Technologien zur Leistungssteigerung in der Zerspan- und Abtragtechnik"). [CD-ROM]. 1. vyd. Dresden: TU Dresden, ISBN -. 